\title{
Human cases of West Nile Virus Infection in north- eastern Italy, 15 June to 15 November 2010
}

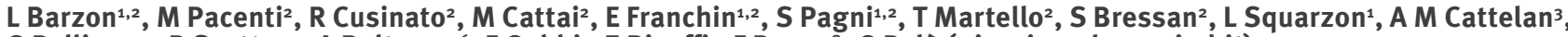

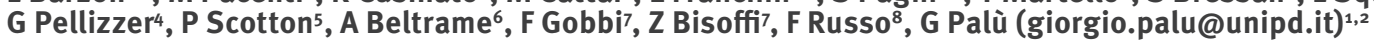

1. Department of Histology, Microbiology and Medical Biotechnology, University of Padova, Padova, Italy

2. Regional Reference Centre for Infectious Diseases, Microbiology and Virology Unit, Padova University Hospital, Padova, Italy

3. Infectious Diseases Unit, Rovigo City Hospital, Rovigo, Italy

4. Infectious Disease Unit, Vicenza City Hospital, Vicenza, Italy

5. Infectious Disease Unit, Treviso City Hospital, Treviso, Italy

6. Clinic of Infectious Diseases, Department of Clinical and Morphological Research, S. M. Misericordia University Hospital, Udine, Italy

7. Center for Tropical Diseases, Sacro Cuore Hospital, Negrar, Verona, Italy

8. Department of Public Health and Screening, Veneto Region, Venice, Italy

Citation style for this article:

Barzon L, Pacenti M, Cusinato R, Cattai M, Franchin E, Pagni S, Martello T, Bressan S, Squarzon L, Cattelan AM, Pellizzer G, Scotton P, Beltrame A, Gobbi F, Bisoffi Z, Russo F, Palù G. Human cases of West Nile Virus Infection in north-eastern Italy, 15 June to 15 November 2010

Russo F, Palù G. Human cases of West Nile Virus Infection in north-eastern Italy, 15 June to 15 November 2010.
Euro Surveill. 2011;16(33):pii=19949. Available online: http://www.eurosurveillance.org/ViewArticle.aspx?Articleld=19949

Article published on 18 August 2011

In 2010, for the third consecutive year, human cases of West Nile virus (WNV) infection, including three confirmed cases of neuroinvasive disease and three confirmed cases of West Nile fever, were identified in north-eastern Italy. While in 2008 and 2009 all human cases of WNV disease were recorded in the south of the Veneto region, cases of WNV disease in 2010 additionally occurred in two relatively small northern areas of Veneto, located outside those with WNV circulation in the previous years. WNV IgG antibody prevalence in blood donors resident in Veneto was estimated as ranging from 3.2 per 1,000 in areas not affected by cases of WNV disease to 33.3 per 1,000 in a highly affected area of the Rovigo province. No further autochthonous human cases of WNV disease were notified in Italy in 2010. The recurrence of human cases of WNV infection for the third consecutive year strongly suggests WNV has become endemic in north-eastern Italy.

\section{Introduction}

In Italy, the first outbreak of West Nile virus (WNV) infection was reported in 1998 and occurred among horses in the Tuscany region [1]. The virus re-emerged in 2008, when equine and human cases of West Nile neuroinvasive disease (WNND) were notified in the Veneto and Emilia Romagna regions in north-eastern Italy [2]. In Veneto, six clinical cases of WNV infection were identified with disease onset from August to September 2008 and all were from the Rovigo province [3,4]; three further human cases of WNND were notified in Emilia Romagna in September and October $2008[4,5]$. Veterinary and entomological surveillance documented that WNV infection was widespread in the same areas in north-eastern Italy, with notification of 794 equine WNV infections in 251 stables and viral isolation in resident bird species and mosquitoes [2]. Compared to 2008, a trend towards an increasing number of human WNV infections and a spread to a wider geographical area was noticed in 2009 [2], when 17 cases of WNND were notified in northern Italy, including six from Veneto, nine from Emilia-Romagna, and two from the Lombardia region [6-8]. In 2009, we isolated the virus from a blood donor and sequenced its whole genome (Itao9, GenBank accession number GU011992) [7]. Phylogenetic analysis classified the Itao9 isolate as Lineage 1 , clade $1 \mathrm{a}$, within the Mediterranean subtype [7], which includes the majority of strains responsible for outbreaks in Europe and in the Mediterranean basin. The full length genome of WNV Itao9 was almost identical to that of WNV isolated from two magpies the year before in the same area [7] and to WNV sequences obtained from mosquito pools collected in Emilia-Romagna in 2009 [9], thus suggesting that WNV might have become endemic in some areas in northern Italy. In these areas, the presence of Culex pipiens vector at high density and resident bird species susceptible to WNV infection, like magpies, carrion crows, and rock pigeons, could play an important role in WNV persistence and maintenance during epizootic periods [2].

In this context, in 2010, enhanced National and Regional Surveillance Plans for WNV surveillance were implemented in Italy. This study reports further human cases of WNV infection, who were identified in Veneto in 2010, also in areas north of those affected in 2008 and 2009.

\section{Methods}

\section{National Surveillance Plan}

During spring 2010, the Ministry of Health published a National Plan for WNND Human Surveillance in Italy, which detailed the activities to be carried out between 15 June and 15 November, the annual period, when the risk for WNV infection is high. In 2010, the surveillance area was enlarged to include municipalities where autochthonous human and veterinary cases of WNV infection had been notified in previous years, as well 
as surrounding areas within $20 \mathrm{~km}$ from the municipalities. Activities included (i) surveillance of human cases of WNND, (ii) active surveillance of WNV disease and serosurveillance of WNV infection in workers employed in farms where equine cases of WNV infection had been identified, (iii) WNV nucleic acid amplification test (NAAT) screening of blood and haematopoietic stem cell donations in areas under surveillance and, of tissue and solid organ donations, on the whole national territory, (iv) measures for mosquito vector control.

\section{Regional Surveillance Plan}

In 2010, the Veneto region implemented the activities of the National Surveillance Plan and intensified the surveillance of human cases of WNV infection by activating an enhanced regional surveillance plan for West Nile fever, as well as seroprevalence studies on blood donors resident in at-risk areas of Veneto.

\section{Case definition of West Nile neuroinvasive} disease and West Nile fever

According to the Regional Surveillance Plan implemented in 2010, cases of WNND were defined as being older than 15 years, having fever $\geq 38.5^{\circ} \mathrm{C}$, and neurological symptoms such as encephalitis, meningitis, Guillain-Barré syndrome or acute flaccid paralysis. Cases of West Nile fever were defined as being over 15 years-old, having fever $\geq 38.5^{\circ} \mathrm{C}$ (or history of fever in the last 24 hours) for a period no longer than seven days occurring from 15 July to 15 November, no history of recent travel to tropical countries, and absence of other concomitant diseases which could account for the febrile illness.

Cases of WNND and West Nile fever were further classified as possible, probable or confirmed. Possible cases of WNND or West Nile fever fulfilled the clinical case definition. Probable cases fulfilled the clinical case definition and at least one of the following laboratory criteria: presence of IgM antibodies against WNV by ELISA; seroconversion by ELISA; fourfold increase of IgG antibodies in acute- and convalescent-phase serum samples (preferably with 15 to 20 days between the two samples) by ELISA. Confirmed cases fulfilled the clinical case definition and at least one of the following laboratory criteria: isolation of WNV from blood and/or, for WNND, from cerebrospinal fluid (CSF); presence of IgM antibodies in CSF by ELISA (for WNND); detection of WNV RNA by RT-PCR in blood and/or CSF (for WNND); detection of increasing levels of IgM and IgG antibodies against WNV by ELISA, confirmed by plaque-reduction neutralisation test (PRNT).

\section{Case laboratory investigations}

Possible cases of WNND and West Nile fever occurring in Veneto were referred to the Regional Reference Laboratory. WNV RNA in plasma and CSF samples was detected by using two different real-time RT-PCR methods, targeting WNV lineage 1 [10] and both WNV lineage 1 and lineage 2 [11]; detection of IgM and IgG antibodies against WNV in serum and CSF samples was done by ELISA (WNV IgM capture DxSelect ELISA and IgG DxSelect ELISA kits, Focus Diagnostics, Cypress, California). To confirm the specificity of antibody response, ELISA-positive samples were further tested by PRNT90, with cutoff 1:10 for positive results. PRNT was conducted in a biosafety level 3 laboratory, according to the protocol described in the Manual of Diagnostic Tests and Vaccines for Terrestrial Animals 2008 of the World Organisation for Animal Health (OIE) [12].

\section{Active surveillance of stable workers}

and household contacts

Active surveillance of WNV infection was done for workers employed in farms and for subjects aged $\geq 15$ years residing in farms where equine cases of WNV infection had been identified. Members of households with confirmed cases of WNND or West Nile fever and close contacts of identified human or equine cases of WNV disease were also surveyed. Laboratory tests included detection of IgM and IgG antibodies against WNV in serum and CSF samples by ELISA and confirmation by PRNT, as described above.

\section{Screening of blood and organ donations}

In 2010, during the period of surveillance according to the National Surveillance Plan, NAAT screening was performed for all blood and haematopoietic stem cell donations from the Rovigo and Venice provinces, where human cases of WNND had been identified in 2009. In September 2010, following the notification of the first case of WNND, NAAT screening was extended to the Vicenza province. Screening of tissue and organ donations was performed on the whole national territory.

WNV NAAT screening of blood donors was performed by using Cobas TaqScreen West Nile Virus test on Cobas S201 system (Roche Molecular Diagnostics) or the PROCLEIX WNV Assay on PROCLEIX TIGRIS System (Novartis Diagnostics). WNV NAAT-positive cases were confirmed by detection of seroconversion or increasing levels of IgM and IgG antibodies against WNV by ELISA, confirmed by PRNT, as described above.

Screening of tissue and organ donations was done by WNV NAAT using Cobas TaqScreen West Nile Virus test on a Cobas S201 system (Roche Molecular Diagnostics) and by IgM and IgG ELISA, as described above. Laboratory results had to be provided within 72 hours from donation.

West Nile virus IgG seroprevalence study The prevalence of WNV IgG antibodies was investigated in serum samples collected from 4,450 blood donors (about $6 \%$ of blood donation collected during the study period), who were referred to four blood donation centres in different areas in Veneto, in the period from 1 August to 1 December, 2010 (Table). Sample size was determined on the basis of an expected prevalence of 6.8 per 1,000 , as determined by a WNV seroprevalence study performed in 2009 [13]. The design and 
the results of the seroprevalence study performed in 2009 are available in the paper by Pezzotti et al. [13]. In 2010, serum samples from 48 blood donations per day were collected for WNV IgG antibody testing. In particular, each day, five donations were sampled from Rovigo, centre 3, 12 from Padova, South-East, 16 from Padova, North, and 15 from Verona, choosing serum samples from the first consecutive daily donors who gave their consent for the study. The number of serum samples collected at each centre was proportional to the volume of donations performed in the year 2009. All samples were handled anonymously by technicians and researchers involved in this study.

WNV IgG testing was done and any IgG-positive sample was further evaluated by PRNT for confirmation, as described above. In addition, in IgG-positive samples, the presence of WNV IgM antibodies was also determined as described above.

\section{Results}

\section{Human cases of West Nile}

\section{neuroinvasive disease}

During the surveillance period in 2010, three males, aged 41-68 years, of 57 possible cases of WNND were confirmed by laboratory tests (all WNND cases were $\operatorname{IgM}$ and IgG-positive, confirmed by PRNT, while WNV RNA was undetectable in serum and (SF). Disease onset was at the end of August (two cases from the Venice and Vicenza provinces) and in the middle of October (one case from the Venice province) (Figure). Symptoms included fever, vomiting, headache, altered mental status, and, in one patient, urinary retention. All patients fully recovered.

\section{FIGURE}

Map of north-eastern Italy representing autochthonous human cases of West Nile neuroinvasive disease and West Nile fever notified in Italy, 2008-2010 $(n=32)$

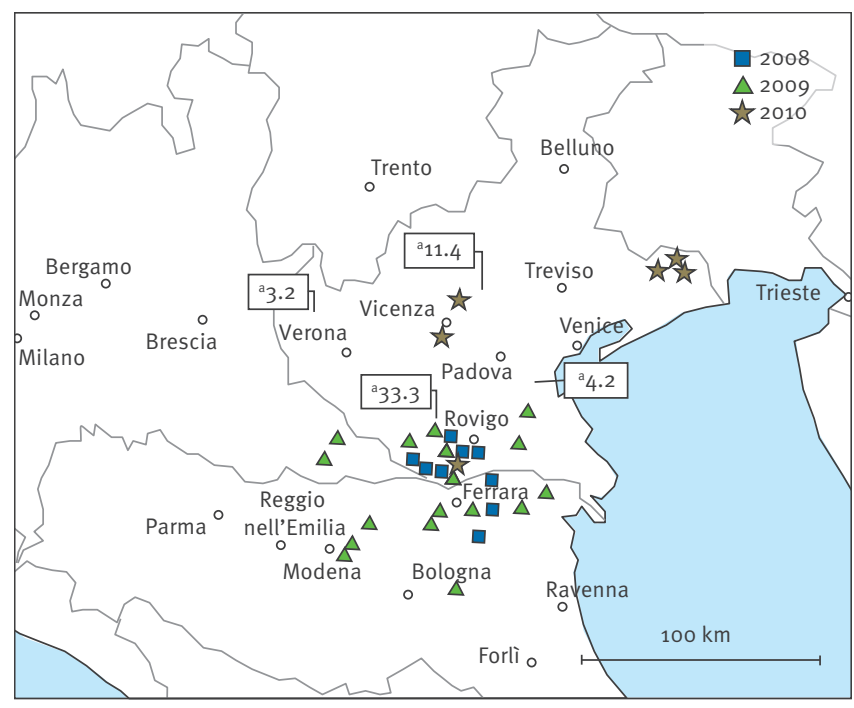

${ }^{a}$ West Nile virus IgG antibody prevalence per 1,000 blood donors, determined in 2010 in four blood donor centres in Veneto.
A further case of WNND was diagnosed in the Rovigo province in the middle of November 2010. The case, aged in its late $40 \mathrm{~s}$, had been hospitalised one month before for viral encephalitis in Romania, in the Braila region, close to areas, where several human cases of WNV disease had been reported in 2010 [14]. This case was therefore considered as an imported case. The patient, who suffered from fever, headache, paraplegia, diarrhoea, myalgia, and pyramidal deficits in both limbs, showed progressive neurological improvement. Laboratory investigation confirmed the presence of IgM and IgG antibodies against WNV.

\section{Human cases of West Nile fever}

Of 38 possible cases of WNV infection, three (two males and one female, aged 40-67 years) were positive for WNV IgM and IgG and confirmed by PRNT test, but none of them was WNV RNA-positive. Symptoms included fever, arthralgia, and asthenia in two patients, and fever, headache, abdominal pain, vomit, and diarrhoea in one. One of these patients, after two weeks of fever and arthralgia, showed asthenia, disorientation and retarded movements. All patients fully recovered. Of these three patients, one was resident in the Rovigo province and was the first case of WNV infection identified in 2010, with symptom onset at the beginning of July, one was resident in the Venice province, and one in the Vicenza province (Figure). A further patient from Rovigo, with a retrospective diagnosis of fever, arthralgia, rash, asthenia, and PRNT-confirmed WNV IgG, but IgM-negative, was defined as a probable case.

\section{Active surveillance of stable workers}

and household contacts

Twelve of 23 household contacts with WNV disease patients were investigated and, among them, an asymptomatic subject resident in Vicenza was found to be WNV IgM and IgG-positive. Active surveillance of WNV infection was also done in all seven workers employed in stables in the Venice province, where equine cases of WNND had been identified [15]. All of them were WNV seronegative.

\section{Surveillance of blood and organ donations}

Of 46,045 screened blood donations, two were WNV RNA-positive and were collected in the middle of September from asymptomatic subjects, one resident in the Rovigo province and the other in the Venice province, in the same area where symptomatic cases of WNV infection had occurred. WNV infection was confirmed in both subjects by seroconversion and by real-time RT-PCR targeting WNV lineage 1 , thus indicating that these were cases of WNV lineage 1 infection. Due to the low viral load, viral genome sequencing was unsuccessful. No cases of WNV infection were identified among tissue and organ donations.

West Nile virus IgG seroprevalence study in blood donors resident in the Veneto region Compared to 2009, the seroprevalence investigation in 2010 was extended to more provinces than the Rovigo 
province, by adding blood donor centres in the Padova and Verona provinces, as detailed in the Table. In 2010, WNV IgG seroprevalence ranged from 3.2 to 33.3 per 1,000 in the different centres. When compared with 2009, a two-fold increase of IgG WNV seroprevalence was observed in the blood donation centre Rovigo, centre 3, which was included in the study both in 2009 and 2010 (Table).

\section{Distribution of cases of West Nile virus disease} All confirmed autochthonous human cases of WNV disease, including WNND and West Nile fever, identified in Italy in the period from 2008 to 2010 are shown on the map in the Figure. Estimated values of WNV seroprevalence in blood donors from the four centres evaluated in 2010 are also indicated on the map (Figure). While in 2008 and 2009 all human cases of WNV disease were identified in the south of Veneto and in neighbouring Emilia Romagna and Lombardia, in 2010, human cases of WNV disease also occurred in two relatively small areas north of the Venice province, as well as in the Vicenza province in Veneto.

\section{Discussion and conclusions}

This study reports six cases of symptomatic and three cases of asymptomatic WNV infection, detected in north-eastern Italy in 2010, an area where WNV seroprevalence was estimated to range from 3 to 33 per 1,000 in 2010. To our knowledge, no further autochthonous human cases of WNV disease were notified in Italy in 2010.

2010 is the third consecutive year that human cases of WNV infection are identified in north-eastern Italy. New areas in the Vicenza and Venice provinces of Veneto, located outside those with WNV circulation in the previous years, have been affected in 2010. A new geographic pattern of WNV spread has also been documented by equine, avian, and entomologic surveillance performed by the Regional and National
Reference Centre for Exotic Diseases, which identified cases of WNV infection in horses, resident birds, and mosquitoes in several areas in the north-east (Modena, Treviso, Venice, Verona, Rovigo, and Bologna provinces), the centre (Campobasso province), and the south (Foggia and Trapani provinces) of Italy, some of which have not been previously affected by WNV [15]. Since WNV was circulating in animals in several areas of Italy in 2010, the identification of human cases of WNV disease only in Veneto could be related to the enhanced regional surveillance programme in this region, which was activated in 2010 .

Besides autochthonous human cases of WNV infection, we diagnosed a case of WNND imported from Romania, where an epidemic outbreak was ongoing with 57 human cases notified in 2010 [14]. This case report, like the recently described cases of West Nile fever imported from Israel to the Netherlands [16], emphasise the importance of surveillance also for potential imported cases of WNV infection. These imported cases serve as sentinels of the increase in the incidence of WNV disease occurring in 2010 in European and Mediterranean countries, where cases of WNV infection are notified every year, such as Romania ( 57 human cases in 2010), Hungary (three cases in 2010), Israel (24 cases in 2010), and Russia ( 480 cases in 2010) $[14,16-19]$. Moreover, a large human epidemic outbreak with 261 confirmed cases of WNV disease occurred in Greece in 2010, where WNV infection had not been documented in humans before [20]; seven human cases of WNV infection were also confirmed in Turkey [21]. In addition, in 2010, equine outbreaks were reported in Morocco, Portugal, Spain, and Bulgaria $[22,23]$.

In this regard, a recent study on the presence of neutralising antibodies against WNV, detected by neutralisation assay, in intravenous immunoglobulin preparations produced from human plasma samples

TABLE

Prevalence of serum West Nile virus IgG antibodies in blood donors from the Veneto region, Italy, 2009-2010 (n=6,957)

\begin{tabular}{|c|c|c|c|c|c|c|}
\hline \multirow{2}{*}{$\begin{array}{l}\text { Province, blood donor } \\
\text { centre }\end{array}$} & \multicolumn{2}{|c|}{ Number of samples } & \multicolumn{2}{|c|}{$\begin{array}{l}\text { Number (\%) of WNV IgG antibody- } \\
\text { positive samples }\end{array}$} & \multicolumn{2}{|c|}{$\begin{array}{c}\text { Estimated WNV IgG prevalence per } \\
1,000 \text { blood donors }[95 \% \mathrm{Cl}]\end{array}$} \\
\hline & 2010 & 2009 & 2010 & 2009 & 2010 & 2009 \\
\hline Rovigo, centre 1 & NR & 494 & NR & $2(0.40 \%)$ & NR & $\begin{array}{c}4.0 \\
{[0-9.6]}\end{array}$ \\
\hline Rovigo, centre 2 & NR & 1,509 & NR & $6(0.40 \%)$ & NR & $\begin{array}{c}4.0 \\
{[0.8-7.2]}\end{array}$ \\
\hline Rovigo, centre 3 & 511 & 504 & $17(3.33 \%)$ & $9(1.79 \%)$ & $\begin{array}{c}33 \cdot 3 \\
{[17.7-48.8]}\end{array}$ & $\begin{array}{c}17.9 \\
{[6.3-29.4]}\end{array}$ \\
\hline Padova, South-East & 719 & NR & $3(0.42 \%)$ & NR & $\begin{array}{c}4.2 \\
{[0-8.9]}\end{array}$ & NR \\
\hline Padova, North & 1,662 & NR & $19(1.14 \%)$ & NR & $\begin{array}{c}11.4 \\
{[6.3-16.5]} \\
\end{array}$ & NR \\
\hline Verona & 1,558 & NR & $5(0.32 \%)$ & NR & $\begin{array}{l}3.2 \\
{[0.4-6.0]}\end{array}$ & NR \\
\hline
\end{tabular}

NR: not recorded.

WNV: West Nile virus. 
collected in Austria, Germany and the Czech Republic demonstrated increasing titres of neutralising antibodies from 2006 to 2010 [24]. Our study also could suggest an increase of WNV IgG seroprevalence in blood donors resident in areas of WNV circulation from 2008 to 2010. The prevalence of WNV IgG antibodies in Veneto ranged from $0.3 \%$ in areas not affected by WNV circulation to $3 \%$ in affected areas, in line with a previous study performed on solid organ donors in Italy in 2009 [25] and with recent WNV seroprevalence data from Greece [26].

In conclusion, for the third consecutive year, human cases of WNV infection have been identified in northeastern Italy, suggesting WNV has become endemic in this area. In addition, in 2010, veterinary and entomologic surveillance identified WNV circulation in Italian areas that have not been previously affected by WNV infection. An increased incidence of WNV infection in humans and horses has been also reported in other European and Mediterranean countries. This epidemiological situation urges European countries to enhance surveillance of WNV disease, mosquito control activities, and implementation of measures to prevent transmission to humans through blood transfusion and organ donation.

\section{Acknowledgements}

This study was supported by Veneto Region and by the European Commission under FP7, Project 261426 (WINGSWest Nile Integrated Shield Project).

\section{References}

1. Autorino GL, Battisti A, Deubel V, Ferrari G, Forletta R, Giovannini A, et al. West Nile virus epidemic in horses, Tuscany region, Italy. Emerg Infect Dis. 2002;8(12):1372-8.

2. Calistri P, Giovannini A, Hubalek Z, Ionescu A, Monaco F, Savini G, et al. Epidemiology of West Nile in Europe and in the Mediterranean Basin. Open Virol J. 2010;4:29-37.

3. Barzon L, Squarzon L, Cattai M, Franchin E, Pagni S, Cusinato $\mathrm{R}$, et al. West Nile virus infection in Veneto region, Italy, 2008-2009. Euro Surveill. 2009;14(31):pii=19289. Available from: http://www.eurosurveillance.org/ViewArticle. aspx?Articleld=19289

4. Gobbi F, Napoletano G, Piovesan C, Russo F, Angheben A, Rossanese A, et al. Where is West Nile fever? Lessons learnt from recent human cases in northern Italy. Euro Surveill. 2009;14(10):pii=19143. Available from: http://www. eurosurveillance.org/ViewArticle.aspx?Articleld=19143

5. Rossini G, Cavrini F, Pierro A, Macini P, Finarelli AC, Po C, et al. First human case of West Nile virus neuroinvasive infection in Italy, September 2008 - case report. Euro Surveill. 2008;13(41):pii=19002. Available from: http://www. eurosurveillance.org/ViewArticle.aspx?Articleld=19002

6. Rizzo C, Vescio F, Declich S, Finarelli AC, Macini P, Mattivi A, et al. West Nile virus transmission with human cases in Italy, August-September 2009. Euro Surveill. 2009;14(40):pii=19353. Available from: http://www.eurosurveillance.org/ViewArticle. aspx?Articleld $=19353$

7. Barzon L, Franchin E, Squarzon L, Lavezzo E, Toppo S, Martello T, et al. Genome sequence analysis of the first human West Nile virus isolated in Italy in 2009. Euro Surveill. 2009;14(44): pii=19384. Available from: http://www. eurosurveillance.org/ViewArticle.aspx?Articleld $=19384$

8. Angelini P, Tamba M, Finarelli AC, Bellini R, Albieri A, Bonilauri $P$, et al. West Nile virus circulation in EmiliaRomagna, Italy: the integrated surveillance system 2009. Euro Surveill. 2010;15(16):pii=19547. Available from: http://www. eurosurveillance.org/ViewArticle.aspx?Articleld=19547
9. Calzolari M, Bonilauri P, Bellini R, Albieri A, Defilippo F, Maioli $\mathrm{G}$, et al. Evidence of simultaneous circulation of West Nile and Usutu viruses in mosquitoes sampled in Emilia-Romagna region (Italy) in 2009. PLoS One. 2010;5(12):e14324.

10. Lanciotti RS, Kerst AJ, Nasci RS, Godsey MS, Mitchell CJ, Savage HM, et al. Rapid detection of west nile virus from human clinical specimens, field-collected mosquitoes, and avian samples by a TaqMan reverse transcriptase-PCR assay. J Clin Microbiol. 2000;38(11):4066-71.

11. Linke S, Ellerbrok H, Niedrig M, Nitsche A, Pauli G. Detection of West Nile virus lineages 1 and 2 by real-time PCR. J Virol Methods. 2007;146(1-2):355-8.

12. World Organization of Animal Health (OIE). Manual of Diagnostic Tests and Vaccines for Terrestrial Animals. Chapter 2.1.20. - West Nile fever. 2008. Paris:OIE. [Accessed 18 Aug 2011]. Available from: http://www.oie.int/manual-ofdiagnostic-tests-and-vaccines-for-terrestrial-animals/

13. Pezzotti P, Piovesan C, Barzon L, Cusinato R, Cattai M, Pacenti $M$, et al. Prevalence of IgM and IgG antibodies to West Nile virus among blood donors in an affected area of north-eastern Italy, summer 2009. Euro Surveill. 2011;16(10):pii=19814. Available from: http://www.eurosurveillance.org/ViewArticle. aspx?Articleld $=19814$

14. Sirbu A, Ceianu CS, Panculescu-Gatej RI, Vázquez A, Tenorio A, Rebreanu R, et al. Outbreak of West Nile virus infection in humans, Romania, July to October 2010. Euro Surveill. 2011;16(2):pii=19762. Available from: http://www. eurosurveillance.org/ViewArticle.aspx?Articleld $=19762$

15. Istituto G. Caporale, Teramo. West Nile Disease in Italy, 2010. Italian. 04 Feb 2011. Available from: http://sorveglianza.izs.it/ emergenze/west_nile/bollettino_2010/2010.pdf

16. Aboutaleb N, Beersma MF, Wunderink HF, Vossen AC, Visser LG. Case report: West-Nile virus infection in two Dutch travellers returning from Israel. Euro Surveill. 2010;15(34): pii=19649. Available from: http://www.eurosurveillance.org/ViewArticle. aspx?Articleld $=19649$

17. ProMED-mail West Nile virus - Eurasia (og): Russia(VOLGOGRAD). Archive number: 20101003.3582. 3 Oct 2010. Available from: http://www.promedmail.org

18. ProMED-mail. West Nile virus - Eurasia (05): GREECE, HUNGARY, AUSTRIA. Archive number: 20100914.3312.14 Sep 2010. Available from: http://www.promedmail.org

19. Kopel E, Amitai Z, Bin H, Shulman L, Mendelson E, Sheffer R. Surveillance of West Nile virus disease, Tel Aviv district, Israel, 2005 to 2010. Euro Surveill. 2011;16(25): pii: 19894. Available from: http://www.eurosurveillance.org/ViewArticle. aspx?Articleld $=19894$

20. Papa A, Danis K, Baka A, Bakas A, Dougas G, Lytras T, et al. Ongoing outbreak of West Nile virus infections in humans in Greece, July - August 2010. Euro Surveill. 2010;15(34): pii=19644. Available from: http://www. eurosurveillance.org/ViewArticle.aspx?Articleld =19644

21. ProMED-mail. West Nile virus - Eurasia (03): RUSSIA, ITALY, TURKEY. Archive number: 20100908.3235. 8 Sep 2010. Available from: http://www.promedmail.org

22. ProMED-mail. West Nile virus - Eurasia (12): Portugal, equine, OIE. Archive number: 20101028.3910. 28 Oct 2010. Available from: http://www.promedmail.org

23. ProMED-mail. West Nile virus - Eurasia (13): Spain, equine, update. Archive number: 20101119.4203.19 Nov 2010. Availble from: http://www.promedmail.org

24. Rabel PO, Planitzer CB, Farcet MR, Orlinger KK, Ilk R, Barrett $P N$, et al. Increasing West Nile virus antibody titres in central European plasma donors from 2006 to 2010. Euro Surveill. 2011;16(10): pii=19812. Available from: http://www. eurosurveillance.org/ViewArticle.aspx?Articleld=19812

25. Capobianchi MR, Sambri V, Castilletti C, Pierro AM, Rossini G, Gaibani P, et al. Retrospective screening of solid organ donors in Italy, 2009, reveals unpredicted circulation of West Nile virus. Euro Surveill. 2010;15(34):pii=19648. Available from: http://www.eurosurveillance.org/ViewArticle. aspx?Articleld $=19648$

26. Papa A, Perperidou P, Tzouli A, Castilletti C. West Nile virus neutralizing antibodies in humans in Greece. Vector Borne Zoonotic Dis. 2010;10(7):655-8. 